\title{
SOME PATENT ASPECTS OF ATOMIC POWER DEVELOPMENT
}

\author{
BeNNETT BoskeY*
}

In these early years of the Atomic Revolution, a mood of transition is widely manifest. This mood helps to sustain our hopes for achieving, through the atom, not annihilation, but, instead, the vast betterment of all mankind. It affects the scope and the pace of our industrial activities. It exerts its influence on the course of our diplomatic negotiations, as well as on the programs of our great institutions of learning. And, needless to say, it is reflected in the Atomic Energy Act of $1954,{ }^{1}$ the statute which sets the legal bounds of our atomic energy endeavor.

When this important congressional enactment became the law on August 30, I954, the event marked the end of one era and the beginning of another in the atomic energy policy of the United States. A primary aim of the new act was to terminate the tight Atomic Energy Commission monopoly which the Congress had established in the original Atomic Energy Act of $1946 .^{2}$ This was in recognition of the factthough it was by no means a simple fact-that the changes occurring between 1946 and 1954 had gradually made it clear that, if continued, the AEC monopoly would become a national liability. Accordingly, in the 1954 act, by extensive relaxation of the earlier legislative prohibitions, the Congress sought to make it possible for the full talents and resources of the nation to apply themselves energetically and unremittingly to the problems of atomic energy. This does not contemplate merely a greater measure of participation in atomic energy development on the part of the power systems which some day hope to generate, transmit, distribute, and sell the nuclear power. It also contemplates participation by the equipment manufacturers, the chemical companies, the metal fabricators, the processors of all kinds of specially adapted materials, the manufacturers of instruments and controls, and the many other groups whose contributions are needed for the development of the art.

Basically, the problem is not, and has not been, to determine whether nuclear power can actually be produced. We know that it can, and we have known this for probably at least a decade. The real problem is to discover the ways by which nuclear power can be produced on an economic basis, genuinely competitively with the cost of power from conventional sources. For the regions where conventional power comes at high cost, such a competitive basis may now seem to be on the horizon; ${ }^{3}$ but for the regions where conventional power comes at medium or low

\footnotetext{
- A.B. I935, Williams College; LL.B. x939, Harvard University. Member of the District of Columbia bar. Formerly Deputy General Counsel, United States Atomic Energy Commission. Contributor to legal periodicals.

168 STAT. 92I, 42 U.S.C.A. \$\$20II-228I (Supp. 1954).

${ }^{2} 60$ STAT. 755, 42 U.S.C. $\$ 180 I-19$ (1946).

${ }^{3}$ Elsewhere in this symposium, the economic factors are considered in greater detail. See Leppke,
} 
cost, the struggle to achieve the necessary cost reductions has hardly begun. The rapidity with which this can be accomplished will be a measure of the act's success in carrying out its declared purpose, in section 3 (a), of "conducting, assisting, and fostering research and development in order to encourage maximum scientific and industrial progress."

The $x 954$ act was intended to encourage and facilitate the widespread dissemination of the abundant technical information and know-how which, though previously narrowly confined, must be made more generally available if our atomic progress is to flourish. Likewise, it was intended to enable private enterprise (including publicpower groups) to develop, invest in, and own facilities-and the components of facilities-which will produce nuclear power and special nuclear material. And in many ways, the new act specifically addresses itself to these problems of transition, at least so far as such problems could readily be foreseen. The Congress certainly hoped that the legislation would create conditions under which, as the state of the art permitted, changes could be effected promptly, taking full advantage of technological advances and the teachings of experience. At the same time, numerous statutory safeguards were adopted in order to maintain what the Congress felt was a proper balance between private interests and the public interest.

This paper will discuss some of the patent aspects of the Atomic Energy Act of 1954. Patents may appear to be a subject of rather narrow scope, but they are here referred to in their broader sense-their relation to the advancement of technology, their significance for the development of atomic power, their effects upon the practices and habits of industry, the special problems encountered in a transitional period, and the nature of the balancing safeguards included in the act.

Patent laws, it must be remembered, are not ends in themselves, but rather the means by which society seeks to attain objectives of high importance. As Chief Justice Marshall said in one of the Supreme Court's very early patent opinions, "To promote the progress of useful arts is the interest and policy of every enlightened government." ${ }^{15}$ Traditionally, and virtually since the birth of the Republic, the United States has looked to the patent system to provide a stimulus to our scientific and industrial progress. It is in no sense the only stimulus, but it is a powerful one.

The significant benefits of the patent system may be summarized very simply: A patent confers a temporary legal monopoly. The promise of this temporary patent monopoly creates a prospect of pecuniary reward. It fosters inventive effort on the part of both the small inventor and the large company. In many instances, it supplies justification for the huge outlays of private capital required to support the

The Facts of Atomic Power Development, supra, 3-13; Tybout, The Public Investment in Atomic Pouver Development, supra, 60-90. In addition, for a summary of some of the best cvidence and opinion now available, consult the papers delivered at the International Conference for the Peaceful Uses of Atomic Energy, held in Geneva, Switzerland, August 1955, particularly, Economics of Nuclear Power, by James A. Lane, of Oak Ridge National Laboratory, and Capital Investment Required for Nuclear Energy, by

W. Kenneth Davis, Director of the AEC's Division of Reactor Development.

68 Stat. 922, 42 U.S.C.A. \$2013(a) (Supp. 1954).

${ }^{5}$ Grant v. Raymond, 1o U.S. (6 Pet.) 218, 241 (1832). 
intensive research and development effort which must so often precede the moment of invention or discovery. And, at the same time, this temporary legal monopoly provides an inducement for the inventor to make a public disclosure of his technical achievements which, when thus disclosed through publication of the patent, become available to the country as a whole as a base for further technological advancement. The public interest thus benefits both from the stimulation of inventive effort and from the public disclosure. ${ }^{6}$

The patent system, to be sure, is not without its pitfalls and its abuses. But since the very first Patent Act of I790, it has been our consistent judgment that the wise and prudent national policy is to strengthen and conserve the patent system. We have sought to remedy the abusive practices not by destroying or undermining the patent system as a whole, but by fashioning specific measures adequate to cope with the abuses. ${ }^{7}$

These broad considerations are all well known. They are mentioned here, however, in order to be sure that the discussion of the special patent aspects of the atom does not become too distantly separated from its more general setting.

The Atomic Energy Act of 1954 is a statute of unusual length. It occupies forty-two closely printed pages, and, thus, is considerably longer than the United States Constitution as originally adopted. About six of the act's pages deal directly and extensively with various aspects of patents and inventions. Instead of undertaking to cover every one of these patent and invention provisions, ${ }^{8}$ this discussion rather will concentrate on certain of their aspects that are of particular interest at the present time-namely, the incentives provided by patents and awards in the field of atomic energy; compulsory licensing; the special reporting requirements for atomic energy inventions; and the troublesome, and perhaps largely unanticipated, patent difficulties which the law creates in connection with contracts, subcontracts, arrangements, and "other relationships" with the Commission.

In considering all such matters, it is well to bear in mind the overriding importance of attaining in this country a maximum level of invention and technological

\footnotetext{
- To quote once again from Chief Justice Marshall's opinion in Grant v. Raymond, supra, the patent "is the reward stipulated for the advantages derived by the public for the exertions of the individual, and is intended as a stimulus to those exertions." Io U.S. (6 Pet.) at $24 \mathrm{I}-42$.

${ }^{7}$ For example, the antitrust litigation of the past few decades has unearthed a variety of abusive patent practices which have met with vigorous corrective action by the federal courts. E.g., HartfordEmpire Co. v. United States, 323 U.S. 386 (1945); United States v. United States Gypsum Co., 333 U.S: 364 (1948); United States v. New Wrinkle, 342 U.S. 371 (1952). The Atomic Energy Act of 1954 contains affirmative provisions designed to reduce the opportunities for antitrust violations to occur in the atomic energy field. See particularly the general provisions in $\$ 105,68$ STAT. 938, 42 U.S.C.A. \$2135 (Supp. 1954); and the further provision in \$158, 68 STAT. 947, 42 U.S.C.A. \$2x88 (Supp. x954), to the effect that if any patent in the atomic energy field is found by a court to have been intentionally used in a manner so as to violate the antitrust laws, then the court may require the patent to be subject to compulsory licensing on a reasonable royalty basis, and this is "in addition to any other lawful sanctions."

${ }^{8}$ In an article entitled Patents Under the New Atomic Energy Act, 36 J. Pat. OFF. Soc'y 867 (1954), I have attempted to discuss, at least briefly, each of the act's provisions relating to patents and inventions. See also the illuminating address by Casper W. Ooms, Revisions of the Patent ProvisionsGood or Bad?, National Industrial Conference Board, Conference on Atomic Energy in Industry 279 (I954).
} 
advancement throughout the field of atomic energy. We live in a world intensely competitive. On both the national defense and the peaceful sides of the atom, the necessity of maintaining our position of leadership is generally understood. Perhaps after the International Conference for the Peaceful Uses of Atomic Energy, held in Geneva, Switzerland, in August 1955, this has become understood even more clearly than it was before.

Great as our atomic energy progress has been since 1942, we know vaguely that we are yet only on the threshold of discovery. There is still truth today in what John Stuart Mill wrote more than a hundred years ago:

Our knowledge of the properties and laws of physical objects shows no sign of approaching its ultimate boundaries; it is advancing more rapidly, and in a greater number of directions at once, than in any previous age or generation, and affording such frequent glimpses of unexplored fields beyond, as to justify the belief that our acquaintance with nature is still almost in its infancy.

How well, therefore, are the patent provisions of the 1954 Atomic Energy Act adapted to speeding us forward into these "unexplored fields beyond"?

The System of Patent and Award Incentives

To understand what the 1954 act accomplishes by way of patent incentives, it is necessary to consider the situation which the $x 946$ act created and then to reflect upon how that has been modified. ${ }^{10}$

A basic feature of the 1946 act was that it removed from the regular patent system two important areas-first, atomic weapons, and second, the production of fissionable material. The reasoning underlying this was clear and simple. The two areas were, under the 1946 act, areas of government monopoly; accordingly, in these areas, the private monopoly of a patent could have no scope for normal operation and hence would have little meaning. What the 1946 act provided was that an invention, to the extent it was useful in either of these areas, should be excluded from the regular patent system. The inventor was, to that extent, disabled from obtaining a patent monopoly on it. But the act did not lose sight of the importance of providing some substitute pecuniary incentive and reward in these areas. This was supplied by affording to the inventor-in lieu of the right to obtain a patent-a right to apply for and obtain a statutory award from the Commission in a formal proceeding conducted before the AEC Patent Compensation Board. The amount of the award was left to the Board to determine in the light of certain valuation standards set forth in the act.11

' John Stuart Mill, Principles of Political Economy Bk. 4, c. I, \$2, at 422 (Pcople's cd. i880).

${ }^{10}$ For more extensive discussion of patent developments under the original Atomic Energy Act, sce Ooms, The Patent Provisions of the Atomic Energy Act, 15 U. CHI. L. Rev. 822 (x948); Boskey, Inventions and the Atom, 50 Colum. L. Rev. 433, and 32 J. Pat. OFf. Soc'Y 563 (r950); Boskcy, Operation of the Patent Provisions of the Atomic Energy Act, 32 J. PAT. OFF. Soc'y 808 (1950); Ooms, Problems of Patent Policy for Government and Industry in Atomic Energy, in ATOMic ENERGy Industrial and Legal Problems I55 (1952).

${ }^{11}$ The work of the AEC Patent Compensation Board under the 1946 act is considered at some length 
In the new act of 1954 , the entire field of atomic energy development is restored to the patent system, except for the area of atomic weapons which remains very much as before. Atomic weapons production has, for obvious reasons, been kept a government monopoly, and, as a corollary, the atomic weapons area has been left outside the regular patent system. Thus, an invention still cannot be the subject of patent rights to the extent that the invention is useful "in the utilization of special nuclear material or atomic energy" in atomic weapons; this is the consequence of the terms of section I5I of the act. ${ }^{12}$ In such a case, the inventor has the same right which he had previously-that is, to apply to the AEC Patent Compensation Board for a suitable award..$^{13}$

In view of the government monopoly over atomic weapons production, however, a patent itself would hardly do any more for the inventor, other than to confer the rather doubtful privilege of being able to proceed in the first instance in the Court of Claims ${ }^{14}$ instead of before the AEC Patent Compensation Board, whose decisions are subject to judicial review. ${ }^{15}$ Indeed, though generalization may be risky, there seems to be good ground for taking the view that an inventor who has made a real contribution in the atomic weapons area is likely to fare better in an award proceeding before the AEC Patent Compensation Board than he would in a suit in the Court of Claims. ${ }^{16}$ Under all the circumstances, therefore, it is hard to believe that the exclusion of the atomic weapons area from the regular patent system actually has any negative effect on technical progress, or that any greater stimulation of invention would be provided if patent rights were allowed to extend into this area.

There are, of course, problems of interpretation which this portion of the act brings with it-for example, questions as to the exact limit of the definition of

in the articles cited in note ro, supra. Under the 1954 act, the principles applicable to proceedings before the Board will continue to be largely along lines begun under the 1946 act, but it may now be necessary for the Board to function on a much more extensive scale. A significant rise in the volume of cases brought to the Board is likely to result from the great increase in the amount of independent work which will now be carried on in the atomic energy field. Moreover, as will appear below, the Board's statutory jurisdiction to grant awards has been substantially broadened by the 1954 act. In addition, by virtue of $\$ 173$ of the act, 68 STAT. 953, 42 U.S.C.A. \$2223 (Supp. 1954), and of the recently promulgated §80.ro(d) of the Commission's regulations, 20 FED. REG. 393I (I955), the Board now has jurisdiction to determine the just compensation to be paid in the event that restricted data contained in a privately owned patent application is communicated by the AEC to some foreign nation. See also, AEC Eighteentr Seminnual Rep. 100 ( 1955 ). It is important to note that the procedural changes which the Commission has made in its regulations subsequent to the new act, 20 FED. REG. 393I (I955), do not modify the basic provision, $\$ 80.60(\mathrm{c})$, of the regulations adopted by the Commission under the I946 act to the effect that "the order of the Board shall constitute the final action of the Commission."

1268 STAT. 943, 42 U.S.C.A. \$218I (Supp. I954).

${ }^{13}$ See $\$ 157,68$ StaT. 947, 42 U.S.C.A. \$2r87 (Supp. 1954).

14 Pursuant to 28 U.S.C. $\$ 1498$ (Supp. 1952).

${ }^{15}$ See $\$ 189,68$ STAT. 955, 42 U.S.C.A. \$2239 (Supp. r954).

${ }^{10}$ One of the reasons for this is that the Board is more likely to be able to grapple successfully with the problem of secrecy-which may be particularly acute in the atomic weapons area-and to give proper evaluation to the contribution which the inventor has made. See Boskey, Inventions and the Atom, 50 Colvm. L. Rev. 433, 440-46, and 32 J. PAT. Off. Soc'y 563, 572-8I (I950). 
"atomic weapon" which appears in section II(d). ${ }^{17}$ But such peripheral problems do not appear to be of large dimension, nor do they create major uncertainties which would impair the effectiveness of the act.

Thus, in the atomic weapons area, the patent situation remains essentially as before. Perhaps one further point should be noted, since it is of particular interest in connection with atomic power development. An invention may have a double usefulness; it may be useful in the atomic weapons area and useful likewise, for example, in the production of special nuclear material. The act makes it clear that the exclusion of such an invention from the patent system is an exclusion which operates only to the extent the invention is useful in the atomic weapons area. With respect to its other uses, this same invention may be the subject of a patent to which normal patent rights attach. This is the result of the basic change of approach which the 1954 act embodies. For, in the 1954 act, as a concomitant of the changes which now make it possible for private enterprises to own their own reactors and other facilities for the production of fissionable material, the whole area of inventions useful in the production of fissionable material is restored to the patent system. Moreover-although this was sometimes overlooked-the area of inventions useful in the production of nuclear power had never been taken out of the patent system, even by the 1946 act. $^{18}$ Consequently, the entire field of atomic power development is now, for all practical purposes, firmly within the patent system which operates in other industrial fields.

This must, however, be understood to be subject to certain special conditions which the Atomic Energy Act makes applicable to inventions in the field of atomic energy alone. The most important of these special conditions arise from the provisions on compulsory licensing, on reporting requirements, and on commission relationships-all to be discussed below. Before proceeding to that discussion, however, an additional word should be said concerning an extra incentive which the I954 act provides in the form of a right to an award.

Under the 1946 act, the right to an award was established only as a substitute for patent rights. But in the new act, while the right to a patent has, as we have seen, been broadened considerably, nevertheless, the right to an award has not been correspondingly narrowed; instead, it too has been broadened. This becomes ap-

${ }^{17} 68$ STAT. 922, 42 U.S.C.A. $\$ 20 \mathrm{r}_{4}$ (d) (Supp. 1954). Note, however, that the definition of "atomic weapon" in $\$ I I(d)$, when read in conjunction with the definition of "atomic encrgy" in $\$ 1 I$ (c), 68 STAT. 922, 42 U.S.C.A. \$2014(c) (Supp. 1954), establishes that "atomic weapon" is meant to include fusion weapons as well as fission weapons-that is, $\mathrm{H}$-bombs as well as A-bombs. The language of the act makes this clear, as does the legislative report of the Joint Committee on Atomic Encrgy, which states, "This definition [of "atomic energy'] includes both fission and fusion types of nuclear reactions." H.R. Rep. No. $218 \mathrm{r}, 83 \mathrm{~d}$ Cong., $2 \mathrm{~d}$ Sess. $1 \mathrm{I}$ (1954).

${ }^{18}$ This was with the possible exception of inventions used simultaneously (as, for example, in a dual. purpose reactor) to produce both nuclear power and fissionable material. See Boskey, The Atomic Encrgy Act and the Power Question, Nucleonics, Oct. 1952, pp. 10, 13; and also testimony before the Joint Committee on Atomic Energy on May Ir, 1954, in Hearings before the Joint Committee on Alomic "Energy on S. 3323 and H.R. 8862, To Amend the Atomic Energy Act of 1946, 83d Cong., 2d Scss., pt. $\mathrm{I}$, at 129 (1954). The term "fissionable material," which was used in the 1946 act, has been superseded by "special nuclear material" in the I954 act. 
parent from section 157 (b) (3), which provides in substance that any person "making any invention or discovery useful in the production or utilization of special nuclear material or atomic energy" may apply to the AEC for an award and that the AEC may grant an award.19 Thus, the right to apply for an award is by no means confined to the atomic weapons area, which is the only area now excluded from the patent system. By a deliberate decision of the Congress, the award system has been extended throughout virtually the entire atomic energy field. It is a stimulus which the 1954 act has provided in addition to, rather than merely in lieu of, the right to obtain a patent, and it affords the inventor an opportunity both for recognition and for pecuniary reward which is supplemental to his rights under the patent system. ${ }^{20}$

Particularly to the small inventor who is able and willing to perform independent work in the field of atomic power development, this additional stimulus may be a matter of especial importance. The field is one where the serious prosecution of a patent application, at least in the case of a somewhat complex invention, may become highly expensive and burdensome. Moreover, the hazards and uncertainties of the ultimate outcome in the Patent Office are greatly increased because of the vast amount of prior art that has been kept from public disclosure by virtue of Patent Office secrecy orders often extending over a period of many years. ${ }^{21}$ Accordingly, whereas the prospect of trying to prosecute a patent application may, in some cases, seem rather bleak and uninviting, in those same cases, the possibility of obtaining a statutory award under section 157 (b) (3) of the act may provide a genuine incentive. $^{22}$

${ }^{20} 68$ STAT. 947, 42 U.S.C.A. $\$ 2 \times 87$ (b) (3) (Supp. 1954).

${ }^{20}$ In connection with the use of awards as a supplemental stimulus to invention, it should be noted that on July 30 , 1955, the House of Representatives passed H.R. 2383 (to be called the Inventive Contributions Awards Act), IOI Cong. Rec. ro602 (daily ed. July 30, r955), which would authorize the National Inventors Council within the Department of Commerce to make awards for meritorious inventive contributions to the national defense, when such inventive contributions have been communicated to and used by a "defense agency" (exclusive of the AEC). If such legislation is enacted, it would furnish a basis for statutory awards in fields other than atomic energy; and, like the awards (except in the atomic weapons area) under $\$ 157($ b) (3) of the Atomic Energy Act of 1954, such awards would be supplemental to, rather than in lieu of, patent rights. The purpose of the bill is to foster invention for national defense and to remedy the very unsatisfactory situation which presently exists because of the fact that the sole recourse of the inventor is generally in the Court of Claims. See Hearings before Subcommittee No. 3 of the House Committee on the Judiciary on H.R. 639 and H.R. 2383, Inventive Contributions Awards Board, 84th Cong., 2d Sess. (1955); and also H.R. REP. No. 1432, 84th Cong., Ist Sess. (1955). The bill is now pending before the Senate Committee on the Judiciary.

${ }^{21}$ Presumably, these secrecy orders will begin to be lifted more rapidly as a result of the Commission's recent enlargements of the areas of information being declassified. But even in such cases, it is to be anticipated that there will often be a substantial time lag between the declassification of certain technological information and the actual lifting of the Patent Office's secrecy order on the corresponding patent application.

${ }^{22}$ In addition to this statutory right to apply for an award, which is established by the first sentence of $\$ 157(b)(3)$, the second sentence of $\$ 157(b)(3)$ goes on to provide that: "The Commission may also, upon the recommendation of the General Advisory Committee, and with the approval of the President, grant an award for any especially meritorious contribution to the development, use, or control of atomic energy." This latter provision was first used to make an award of $\$ 25,000$ to Enrico Fermi, shortly before his death, and the Commission has announced that future awards of this category will be known as the Fermi Prize. See AEC Seventeenth Semiannual Rep. 38-40 (1955). It should be noted that under the terms of the act, such an award need not necessarily be based on an "invention or discovery," but may be conferred for some other type of "especially meritorious contribution" as well. 


\section{Compulsory Licensing}

The subject of compulsory licensing is highly controversial and often misunderstood. One viewpoint considers that patents in all fields of industrial activity should be subject to some type of compulsory licensing requirements, as they are in certain countries abroad. Another viewpoint considers that any form of compulsory licensing authority-even when confined to the field of atomic energy, and there on a very limited basis-represents a vicious and, indeed, unconstitutional inroad upon the patent system. Perhaps most people take a somewhat middle view, and, in any event, that is what the Congress has done in the 1954 Atomic Energy Act.

In the 1946 act, section II(c), enacted after much heated debate, had given the AEC fairly broad authority-and, indeed, had placed the AEC under a duty-to declare a patent to be affected with the public interest if both of two conditions were met: (x) that the invention "utilizes or is essential in the utilization of fissionable material or atomic energy," and (2) that compulsory licensing was "necessary to effectuate the policies and purposes of this Act." 23 The consequences of thus declaring a patent affected with the public interest would have been twofold. First, the AEC itself would then have been licensed to use the invention on a reasonable royalty basis-a somewhat superfluous grant of authority in view of the general right which the Government possesses to use all patented inventions and to remit the patent owner to his remedy for compensation in the Court of Claims. ${ }^{24}$ Second, and more important, a license to use the invention on a reasonable royalty basis would also have been conferred automatically upon anyone who held a section 7 (of the $1946 \mathrm{act}$ ) license relating to utilization of atomic energy. ${ }^{25}$

No section 7 license relating to utilization of atomic energy was ever issued by the AEC under the 1946 act, because the provisions of section 7 did not come into operation. Accordingly, the occasion for declaring any particular patent to be affected with the public interest did not really ever arise, nor was it ever necessary that the possibility of doing so in a particular case be given serious consideration. The AEC, at a fairly early date, and partly in the hope of allaying some of the public misunderstanding concerning this portion of the act, took pains to describe the compulsory licensing authority as a "reserve power" to be used "under certain rather exceptional circumstances." 26 Thus the matter rested, with the controversy slumbering but not stilled, at the time the act came up for general revision.

In the hearings on the new act, various shades of opinion concerning the compulsory licensing provisions were given full expression before the Joint Committee on Atomic Energy. ${ }^{27}$ The view that prevailed in the Congress was that, during

${ }^{23} 60$ STAT. 768,42 U.S.C. \$I8II(c) $(1946)$.

${ }^{24}$ See 28 U.S.C. \$1498 (Supp. I952).

${ }^{25} 60$ STAT. 764,42 U.S.C. \$1807 (1946).

${ }^{26}$ See AEC Fifth Semianiual Rep. 148 (1948).

${ }^{27}$ Varying views on this aspect of the patent provisions had been expressed by witnesses testifying before the Joint Committee on Atomic Energy during the course of the preliminary hearings, cntitled Atomic Power Development and Private Enterprise, held in June and July 1953 (83d Cong., Ist Sess.). President Eisenhower's message of February 17, 1954, recommending revision in the atomic energy 
this period of transition, for special reasons which would not apply in other fields of industry, it would be advisable to retain a very limited form of compulsory licensing authority in the field of atomic energy. Although voted down by the House, this was insisted upon by the Senate and became a part of the final enactment. 28

The basic purpose of the limited compulsory licensing authority which thus remains in the law is to provide, during the transitional period, a safeguard which will help to assure the widest practicable participation in the atomic energy program. As such a safeguard, it may partially offset the initial inequality of opportunity resulting from the AEC monopoly which existed under the 1946 act but which should largely disappear during the years to come. The power is one which the Commission may never be called upon to exercise; yet, its mere presence in the law is a safety valve which may prevent abusive or unhealthy conditions from being created as this industry emerges from the cocoon of secrecy and government monopoly.

Examination of the detailed compulsory licensing provisions of the 1954 act will show how very strictly the Congress has confined the Commission's authority in this respect, and, hence, how groundless are the fears that some vital inroad has been made upon the patent system. The rather general authority which the Commission possessed under the 1946 act has been considerably narrowed. Under the new act, it is not nearly enough, as it was before, that the invention is found to come within a broadly defined atomic energy field and that the AEC should determine compulsory licensing to be necessary to effectuate the policies and purposes of the act. Instead, section 153 (a) now requires that, before declaring a patent to be affected with the public interest, the Commission must find that the invention "is of primary importance in the production or utilization of special nuclear material or atomic energy"; and before such determination is made, the act directs the Commission to give the patent owner an opportunity for hearing. ${ }^{29}$ Furthermore, section I53(b) (2) requires that, even after such determination has been made, a compulsory license on a reasonable royalty basis shall be issued to a particular applicant only if the Commission finds his proposed use "is of primary importance to the conduct of an activity by such person authorized under this act." ${ }^{30}$ It is not wholly clear

legislation, included a recommendation that some form of compulsory licensing authorization be retained for a limited period because "considerations of fairness require some mechanism to assure that the limited number of companies, which as Government contractors now have access to the program, cannot build a patent monopoly which would exclude others desiring to enter the field." H.R. Doc. No. $328,83 \mathrm{~d}$ Cong., $2 \mathrm{~d}$ Sess. 7 (1955). Considerable testimony on the subject of compulsory licensing, covering a wide range of views, was again received by the Joint Committee in the public hearings which immediately preceded the enactment of the law. See Hearings, supra note I8.

${ }^{28}$ See especially the Statement of the Managers on the Part of the House, in the second conference report, H.R. Rep. No. 2666, 83d Cong., 2d Sess. (r954), appearing at roo Cong. Rec. 14867 (I954), and the accompanying legislative debate. The legislative history is set forth in greater detail in note 44 infra.

${ }^{20} 68$ STAT. 945, 42 U.S.C.A. $\$ 2183$ (a) (Supp. I954).

${ }^{30} 68$ STAT. 945, 42 U.S.C.A. \$2r83(b)(2) (Supp. I954). 
from the act itself whether the patent owner is entitled to a hearing on the issues raised by the particular application, but it appears that the AEC does intend, by its regulations, to assure to the patent owner this important procedural safeguard. ${ }^{31}$

Here then, in consequence of the terms of section ${ }_{53}$ (a) and ${ }_{153}(b)$, is a new double-barreled, "primary importance" test which places significant statutory limitations on the scope of the Commission's authority. While the meaning of the phrase "primary importance" may not be entirely self-evident and may require elucidation from records developed before the Commission in particular cases if they should ever arise, the act itself plainly was intended to lay down a basic principle that the compulsory licensing power cannot be exercised merely as a matter of routine or to carry out some relatively inconsequential purpose.

In addition, section 153 provides an alternative procedure whereby compulsory licensing proceedings may be initiated by an outsider who wants to obtain such a license, rather than by the AEC itself. For such a case, there are detailed procedural provisions which assure the patent owner the protection of a full hearing. Moreover, here the Commission's authority is once again hedged in by the "primary importance" test, but this time on a triple-barreled basis. Not only must the Commission find that the invention is of "primary importance" in the field and that obtaining the compulsory license is of "primary importance" to the applicant; the Commission is also required to find that the applicant's proposed activities are of "primary importance" to the furtherance of policies and purposes of the act. In addition, the Commission must find that the applicant cannot otherwise obtain a patent license from the patent owner on terms which the Commission deems reasonable. Then, and only then, may the AEC issue a compulsory license under this alternative procedure. ${ }^{\mathbf{2}}$

It will, thus, be seen that, under either of the procedures set forth in the statute, the Congress has surrounded the compulsory licensing power by a series of restrictive conditions which would make it virtually impossible for that power to be exercised except in a comparatively rare and factually compelling case. Indeed, this would be true even if the Commission itself were not predisposed-as it so clearly is by its belief in the importance of the patent system-to regard compulsory licensing as a "reserve power." ${ }^{33}$ The power could be exercised, if necessary in some exceptional case, to prevent the progress of the entire industry from being blocked by an unduly

${ }^{31}$ This was not evident either from the proposed regulations on Standard Specifications for the Granting of Patent Licenses, which the AEC issued on April 7, 1955, 20 FED. REG. 2283 (I955), or from the proposed regulations on Rules of Practice, which the AEC issued on August 10, 1955. Id. at 5786. But there have been informal indications that, when the full set of AEC regulations is issued in final form, this safeguard will be expressly provided for.

${ }^{32} 68$ SтAт. 945, 42 U.S.C.A. $\$ 2183$ (c), (d), (e) (Supp. 1954).

${ }^{33} \mathrm{See}$, for example, the Commission's statement in Hearings, supra note 18 , pt. 2, at 597 . In testifying before the Joint Committee on February 4, 1955, in Hearings before the Joint Committee on Atomic Energy on Development, Growth, and State of the Atomic Energy Industry, 84th Cong., 2d Sess. pt. 1 , at I94 (1955), William Mitchell, the AEC General Counsel, stated: "The compulsory licensing provisions of $\$ 153$ of the act are deemed by the Commission to establish a reserve power. It is not anticipated that this authority will be invoked, except under compelling circumstances." 
wide monopoly over a vital invention. Only the future can tell us whether any such situation will ever arise with respect to the inventions or discoveries which come into existence before September I, I959. ${ }^{34}$

\section{REPORTING REQUIREMENTS}

The 1946 act contained a 60-day reporting requirement for inventions in those areas of atomic energy which the act excluded from the regular patent system..$^{35}$ By section $15 \mathrm{r}$ (c) of the 1954 act, the 60 -day period has been increased to 90 days, ${ }^{36}$ and this undoubtedy makes compliance considerably more practicable. But more important, section $\mathrm{I}_{5} \mathrm{I}$ (c) has substantially enlarged the areas of invention that are covered by the reporting requirement.

In its present form, the reporting requirement is not limited to the atomic weapons area, which, as we have noted, is the only area now excluded from the patent system. The requirement reaches out to include also all inventions or discoveries useful either in the "production" or in the "utilization" of either "special nuclear material or atomic energy." The purpose of this provision was described in the Joint Committee's legislative report as being "to keep the Commission fully and currently aware of all technology in the field of atomic energy."37 In other words, no one is authorized to hold back from the Commission any new technological development which might be important in the planning or execution of the Commission's programs and other responsibilities. And what the act calls for in the report is "a complete description" of the invention or discovery.

It will be noted that the terms employed in the reporting provision have an extensive coverage, which would facilitate their being interpreted so as to accomplish their exceptionally broad purpose. Since most inventions in the field of atomic power development either will clearly fall within the scope of this reporting provision, or arguably might do so, it is worth considering, for a moment, what the effects of this important part of the act may be.

${ }^{36} \mathrm{By} \$ \mathrm{I}_{53}(\mathrm{~h})$ of the act, 68 STAT. 945, 42 U.S.C.A. $\$ 2183(\mathrm{~h})$ (Supp. 1954), the compulsory licensing provisions apply to any patent the application for which shall have been filed before September I, I959-in other words, inventions conceived during a period of approximately five years from the enactment of the 1954 act. The Senate had voted to make this period ten years, on the ground that five years would not provide a sufficiently long interim period (see I00 Cong. REc. I2002-03 (1954)), but, on this point, yielded to the House. It should be noted, however, that under the act, the compulsory licensing provisions are applicable to such inventions during the entire seventeen-year life of the patent after the patent has been issued. Indeed, were it otherwise, the compulsory licensing provisions would be virtually meaningless: for one thing, the licensee then would have no assurance of being able to retain the license after the five-year period expired and hence he would hardly be justified in investing any capital on the strength of such a license; for another, the time lag in the Patent Office for prosecution of patent applications means that probably not a great many of the privately owned patents in the field should be expected to issue much before September I, 1959, and, accordingly, the need for the compulsory licensing safeguard, with respect to such inventions, would be most likely to arise after September I, 1959.

${ }^{35}$ See $\S \operatorname{Ir}(a)(3), 60$ STAT. 768,42 U.S.C. $\$ 18 \operatorname{Ir}(a)(3)(1946)$.

${ }^{30} 68$ STAT. 943, 42 U.S.C.A. $\$ 2 \operatorname{Ir8}$ (c) (Supp. 1954).

${ }^{37}$ H.R. Rep. No. 218r, 83d Cong., 2d Sess. 25 (1954). The Commission itself described the purpose of the provision as follows: "By being fully apprised of private invention in this field, the Commission will be in a position to allocate its resources and funds where they are most needed. Without knowledge of private achievement avoidance of duplication of effort cannot be assured." See Hearings, supra note 18 , at 598 . 
First, it should be made clear that section $15 \mathrm{I}(\mathrm{c})$ gives to the inventor an election. Within the 9o-day period, either he must file a patent application in the Patent Office or else he must file an invention report with the AEC, but he is not required to do both. Different considerations may influence his choice in particular cases, but if he is not prepared to undertake the expense and the trouble of filing a patent application, then he is under an affirmative duty to report the invention to the AEC. If he does elect to file a patent application, the invention, in due course, will presumably be made known to the AEC by the Commissioner of Patents, in view of section ${ }^{5} \mathrm{I}^{\mathrm{I}}(\mathrm{d})$ of the act, which requires the Commissioner of Patents to notify the $A E C$ and provide the AEC with access to all patent applications which, in the Commssioner's opinion, disclose inventions within the categories listed in the reporting requirements of section $15 \mathrm{r}(\mathrm{c}){ }^{38}$

Next, there is the question of computation of the go-day reporting period. The act fixes the time as on or before the ninetieth day after whichever of two events is later-either the ninetieth day after "completion of such invention," or the ninetieth day after the inventor "first discovers or first has reason to believe" that the invention is useful in such production or utilization. This language is not substantially different from that in the 1946 act, but it raises a number of practical problems as to interpretation. For example, the meaning of the word "completion" is not fully self-explanatory and will have to be considered carefully in the light of all the circumstances of the particular case. Questions of this type have not yet come up for administrative or judicial decision under either the 1946 or the 1954 act. Until they do, the cautious approach will be to err on the side of filing the report or the patent application too soon rather than too late.

It is perfectly natural for a company or an individual working in this field to wonder what might be the consequences of not complying with the reporting requirements of section $15 \mathrm{I}(\mathrm{c})$. As a matter of principle, of course, most people will want to be sure they are taking adequate steps for compliance, regardless of whether noncompliance might bring with it any serious legal consequences. Moreover, apart from legal consequences, there are the obvious problems as to good reputation and public relations, both of which could be adversely affected by noncompliance.

But the matter does not stop there. There are, in fact, some important legal consequences that need to be considered. One is expressly spelled out in the act, in connection with the statutory awards for inventions in the atomic energy field. Section ${ }_{57} 7$ (b) (3), dealing with eligibility for such awards, makes it a condition of eligibility that the applicant shall have complied with the provisions of section $15 \mathrm{I}(\mathrm{c})$. Hence, an invention which has not been either filed in the Patent Office or reported to the AEC within the stipulated 9o-day period could not be the subject of a statutory award. The AEC Patent Compensation Board has so held in a recent decision, stating that the reporting requirement is "a requirement which this Board may not waive or overlook." 384

${ }^{38} 68$ STAT. 943,42 U.S.C.A. $52 \times 83$ (d) (Supp. 1954).

${ }^{38 a}$ See In re Grossman, Docket No. 77 (Oct. 25, 1955), reported in Atomic Industry Rep. 235:64I, 
Another rather serious legal consequence might arise in connection with activities carried on pursuant to license or permit issued by the AEC. For example, the Commission's regulations provide that access permits, or facilities licenses, or licenses for distribution of special nuclear material shall all be subject to suspension or termination by the AEC for violation of or failure to observe any of the terms of the Atomic Energy Act of 1954 or Commission regulations. ${ }^{39}$ Accordingly, failure to comply with the reporting requirements of section $15^{\mathrm{r}}(\mathrm{c})$ - particularly if such failure were to be continuous and deliberate-could place in jeopardy an access permit or a license which the AEC has issued.

There is also the possibility that the validity of a patent eventually issued to cover the particular invention might be drawn in question if noncompliance with these reporting requirements could be established. This is a point which has not yet been litigated in patent suits involving the interpretation of either the 1946 or the I954 Atomic Energy Act. Perhaps it will not be litigated for some time to come. But in the absence of a definitive adjudication, it would be hard to say with assurance that an inventor who fails to live up to the reporting requirements of section ${ }_{5} \mathrm{I}$ (c) may not also have thrown away his patent rights.

In addition, there is even the possibility that noncompliance with the reporting requirements of section $\mathrm{I}_{5} \mathrm{I}$ (c) might be punishable criminally, if the Government were to establish beyond a reasonable doubt that the violation had been willful. ${ }^{40}$

Section $I_{5} \mathrm{I}(\mathrm{c})$ does not distinguish between inventions of great significance and inventions of small significance; it applies to every "invention or discovery" in the atomic energy field defined. Hence, the reporting requirements cannot safely be ignored merely on the ground that the invention does not measure up to whatever level of importance the company normally looks for when deciding to file and prosecute a patent application. Nor can information be withheld merely on the ground that it constitutes know-how or trade secrets which normally would be tightly held within the company; if such know-how or trade secrets embody an "invention or discovery" within the atomic energy field defined, then the invention or discovery is

235:643 (1955). The case on its facts involved the applicant's failure to comply with the reporting requirements of the 1946 act, but on this point, it is clear that there would have been no difference if the 1954 act had been involved.

${ }^{30}$ See the proposed regulations concerning Access to Restricted Data, \$25.I5, 20 FED. REG. 3635 (1955); Licensing of Production and Utilization Facilities, $\$ 50.100$, id. at 249x; and Special Nuclear Material, $\$ 70.6 \mathrm{r}(\mathrm{b})$, id. at 2494 . It is to be expected that such provisions will be continued when the respective regulations are issued in final form.

${ }^{40}$ Section 223 of the 1954 act provides: "Whoever willfully violates, attempts to violate, or conspires to violate, any provision of this Act for which no penalty is specifically provided ... shall, upon conviction thereof, be punished by a fine of not more than $\$ 5,000$ or by imprisonment for not more than two years, or both. ..." 68 STAT. 958, 42 U.S.C.A. $\$ 2273$ (Supp. 1954). If this criminal penalty should be determined to be applicable to noncompliance with the reporting requirements of II $_{5}$ I (c), then it would be important to consider in this connection the possible meanings and scope of the word "willfully," as here used. Cf. United States v. Murdock, 290 U.S. 389 (I933); Browder v. United States, 312 U.S. 335, 34I-42 (I94I); Spies v. United States, 3 I7 U.S. 492 (r943); Screws v. United States, 325 U.S. $9 \mathrm{I}$, I0I-07, I5I-57 (1945). 
plainly subject to the reporting requirements. ${ }^{41}$ Moreover, the fact that the invention may be developed during the course of a contract with the Army, the Navy, the Air Force, or some other federal agency besides the AEC, and, hence, may be subject to a separate reporting requirement of the government agency which has let the contract, would not appear to justify or excuse noncompliance with section I5I(c). In addition, nothing in the act appears to confer upon the Commission itself an authority to grant extension of time, and hence it is doubtful whether the Commission would be authorized to grant, by contract or otherwise, a period longer than the specified go days, even to its own contractors. ${ }^{42}$

All these considerations give to the reporting requirements a practical operating importance which, at first glance, might easily be overlooked. There is probably nothing about the reporting requirements which a well-managed business cannot live with in peace and harmony. But to do so requires careful planning and review, as well as a genuine desire to comply.

\section{Contracts aNd Other ReLationships with the AEC}

Section I52 of the I954 act has a title, "Inventions Conceived During Commission Contracts," which hardly suggests the mischievous and vexatious nature of its contents. ${ }^{43}$ In the Congress, the legislative process does not always move with complete smoothness and efficiency-particularly toward the end of a long and controversial session. Section 152 evidences some of the weaknesses inherent in the legislative process, just as certain other portions of the act stand as monuments to its strength.

What Section 152 does by its terms is to vest in the Government, rather than in the inventor, the ownership of atomic energy inventions conceived under contracts, subcontracts, arrangements, or "other relationships" with the Commission, except to the extent that the Commission may waive such rights of the Government. That this is an unintentionally far-reaching and troublesome provision has now become apparent.

Perhaps the most important contributing factor to the section 152 difficulties was the fact that neither its provisions nor anything like them were in the bill at the time of the main public hearings held by the Joint Committee on Atomic Energy.

\footnotetext{
${ }^{41}$ It may well be, however, that if appropriate justification is furnished, the Commission will be prepared to maintain the confidentiality of trade secrets. Cf. $\$ 2.790$ of the proposed AEC Rules of Practice, relating to requests for withholding documents from public inspection. 20 FED. REc. 5792 (1955).

${ }^{43}$ Section $16 \mathrm{r}(\mathrm{q})$ of the 1954 act, 68 STAT. 948, 42 U.S.C.A. \$220r(q) (Supp. 1954), confers on the Commission authority to "make, promulgate, issue, rescind, and amend such rules and regulations as may be necessary to carry out the purposes of this Act." It would not be easy to bring within that authorization a regulation which purported to relieve the inventor entirely of his obligation to make a report within the go-day period which $\$ I 5 I$ (c) specifically lays down. On the other hand, it might be within the Commission's authority to establish by regulation a system of short-form reporting, which called for filing within the 9o-day period an initial short-form report that would later be amplified. A principal problem in connection with drafting any such regulation, however, would be to devise a shortform report which, nevertheless, met the statutory requirement that the report to be filed within the 90-day period should contain a "complete description" of the invention or discovery.

\$3 68 STAT. 944, 42 U.S.C.A. \$2182 (Supp. 1954).
} 
Thus, section 152 never had the benefit of the public comment and criticism which is so often indispensable in forging legislation that will be truly adequate to meet the problems of the day. What happened was that section 152 was put forward somewhat later, by those who were opposed to the compulsory licensing provisions, in the hope of persuading their colleagues in Congress that section 152 would make it unnecessary to include any compulsory licensing provisions whatsoever. The final result, however, was that instead of selecting between one or the other, the Congress included both sets of provisions in the act. ${ }^{44}$

After the act was passed, the detailed provisions of section 152 began to receive more intensive scrutiny. It has already become apparent that the language of section I52 is giving rise to problems of real magnitude. By its terms, the section is applicable to any invention useful in the production or utilization of special nuclear material or atomic energy if the invention is "made or conceived under any contract, subcontract, arrangement, or other relationship with the Commission, regardless of whether the contract or arrangement involved the expenditure of funds by the Commission." The section goes on to provide that in any such case, the invention "shall be deemed to have been made or conceived by the Commission"-in other words, to be government property rather than the private property of the inventor. The section then contains an exception on which very much hinges. The exception provides that the Commission "may waive its claim" to any such invention "if made or conceived by any person at or in connection with any laboratory under the jurisdiction of the Commission as provided in section $33,{ }^{45}$ or under such circumstances as the Commission may deem appropriate."

4 The bills which served as the principal basis of the testimony given before the Joint Committee on Atomic Energy in the public hearings were H.R. 8862 and S. 3323 , identical bills introduced on April 15, 1954, 83d Cong., 2d Sess. These bills contained neither compulsory licensing provisions nor anything resembling what later became $\$ 152$. After the testimony from the public-though not from government agencies-had been virtually completed, there was prepared and circulated a committee print, dated May 21, 1954, incorporating numerous chr-iges proposed at that time to be made in the bill. This committee print did not contain any compulsory licensing authorization, but it did contain what was a forerunner of the $\$ 152$ finally incorporated in the act. This forerunner of $\$ 152$ received rather critical comment from the Commission in testimony given on June 2, I954. See Hearings, supra note 18 , pt. 2, at 598-99. The bill as reported out by the Joint Committee on June 20, 1954 (H.R. 9757 and S. 3690) contained a limited compulsory licensing authorization but not a $\$ 152$ provision. In that form, it passed the Senate as H.R. 9757, with certain amendments, on July 27, r954. roo Cong. Rec. I2242 (1954). Meanwhile, on July 26, I954, the bill had been passed by the House, id. at 12024-26, after the House, on July 23, 1954, had accepted an amendment offered by Representative Cole which substituted the present $\$ \mathrm{I}_{52}$ for the compulsory licensing provisions. Id. at II721-29. Because of these and other differences between the Senate and the House, the bill went to conference. The first conference report, dated August 6,1954 , retained the $\$ 152$ provisions, but in lieu of compulsory licensing, it sought to introduce a provision directing the Commission to give preferred consideration for $\$ 103$ commercial licenses, during the next five years, to those applicants who agreed to make their patents available on a reasonable royalty basis to all other commission licensees who demonstrated need therefor. See H.R. Rep. No. 2639, 83d Cong., 2d Sess. 36, 48-49 (1954). This conference report was agreed to by the House, Ioo Conc. REc. 13787 (I954), but was rejected by the Senate. Id. at I4364. A second conference report, H.R. REP. No. 2666, $83 \mathrm{~d}$ Cong., $2 \mathrm{~d}$ Sess. (1954), containing the provisions finally incorporated in the 1954 act, was then submitted to and accepted by both House and Senate. 100 CoNG. REc. I4852-73, 14603-06 (1954).

${ }^{4}$ Section 33, 68 STAт. 928, 42 U.S.C.A. $\$ 2053$ (Supp. 1954), covers a special situation-probably of relatively minor importance with respect to the general patent aspects of this subject-where the Com- 
This statutory language furnishes virtually no standards by way of guidance. The general purpose of the sponsors of this amendment appears to have been to put the Commission in a position where the Commission would be able to prevent firms from profiting in an inappropriate manner from their association with the government-financed atomic energy program. ${ }^{46}$ Hence, the Commission is confronted with some very understandable difficulties in determining where it is "appropriate" to relinquish these important property rights which the act otherwise vests in the Government. ${ }^{47}$ Moreover, when the breadth of the coverage is considered-"under any contract, subcontract, arrangement or other relationship with the Commission, regardless of whether the contract or arrangement involved the expenditure of funds by the Commission"-it would be possible to conclude that very few people might be able to own a patent in the field of atomic energy, except by leave of the Commission in the exercise of its discretionary waiver authority. Since the statute expressly provides that the use of federal funds by the inventor is not required in order to bring the relationship within section 152, the terms which the Congress put into this section would appear to have a reach that goes remarkably far. ${ }^{48}$

An obvious question is whether the sweeping language of section 152 would vest in the Government the inventions conceived by a research licensee operating under a section 104 research license from the Commission, ${ }^{40}$ or those conceived by a commercial licensee operating under a section ro3 commercial license from the Commission..$^{50}$ If so, it might appear that section 152 has succeeded in taking back almost the very thing that the other patent provisions of the act were designed to assure. Fortunately, there is some rather direct legislative history indicating that a mere licensee was not intended to be included. ${ }^{51}$

mission carries on research for others in its own facilities because private facilitics are inadequate for the purpose.

${ }^{10}$ In introducing the amendment, Representative Cole stated: "The amendment that I have proposed is to the effect that every application for a patent in this field must carry with it a sworn statement by the applicant telling the time and circumstances and conditions under which this invention or discovery was conceived, and if that information discloses that it was during the course of any employment by the Atomic Energy Commission or employment by a contractor of the Commission or in any relationship whatever with the Federal Government that then the Commission may deny to that applicant the right of a patent and declare that that patent is public property-based upon the argument that it was conceived in the course of an association with the Government which was supported by public funds. That to me accomplishes the objective. It prevents anybody at all-everybody whatsoever who has been engaged in this program from obtaining a patent in the nonmilitary field of atomic cnergy, if that invention or discovery was conceived during the course of any association or relation with the Government." I0o CoNG. REc. II722 (I954).

${ }^{47}$ In this connection, see also the testimony of William Mitchell, AEC General Counscl, in Hearings before the Ioint Committee on Atomic Energy on Development, Growth, and State of the Atomic Energy Industry, 84th Cong., 2d Sess., pt. I, at 194, 197-99 (1955).

${ }^{4}$ Section 152 also provides that, in the event of a controversy between the AEC and the inventor concerning whether the invention was "made or conceived in the course of, in connection with, or under the terms of any contract, subcontract, arrangement, or other relationship with the Commission entitling the Commission to take title to the application or the patent," then such controversy is to be determined by the Board of Patent Interferences, subject to appeal to the Court of Customs and Patent Appeals.

${ }^{10}$ See 68 STAT. 937, 42 U.S.C.A. \$2134 (Supp. I954).

${ }^{60}$ See 68 STAT. 936, 42 U.S.C.A. \$2133 (Supp. x954).

${ }^{51}$ During the debates, Representative Cole, then Chairman of the Joint Committee on Atomic Encrgy, 
Even if this legislative history can safely be relied upon, however, it does not solve the problem of how much more-or, indeed, how little more-there need be before the licensee finds himself enmeshed in section 152. For example, in the ordinary course of arranging for a license from the Commission, consultations may take place between the prospective licensee and the Commission which result in suggestions from the Commission as to the most feasible means of carrying out the proposed project. Will the acceptance of such suggestions create an "arrangement, or other relationship" which catches him up in the section 152 net? Or if, after obtaining the license, the licensee later consults with the Commission concerning technical problems and decides to follow suggestions which the Commission makes, has section I52 then cast a cloud upon all his patent rights in the field? And will the Commission come to the conclusion-as it intimated early in $1955^{52}$-that a licensee who also has access to restricted data is thereby brought within the scope of section I52? $^{2}$ ?

These are only a few of the types of problems which section 152 creates. Most assuredly, there are many more. Some of them, moreover, arise in connection with what would otherwise be regarded as the routine effort to meet procurement needs of the Commission and its contractors. How is a company in the atomic energy field to be able to know that-even if the reach of the terms "contract," "subcontract," and "arrangement" has been successfully avoided-it has still not become involved in some "other relationship with the Commission"? I am not unmindful of Judge Cardozo's caution that "overemphasis of certainty may carry us to the worship of an intolerable rigidity." "53 But surely here in section 152 we are confronted with a kind of harassing uncertainty that is without purpose or utility.

Mr. Ooms has indicated that anyone who writes a letter to the Commission may have to worry about whether he is in trouble under section $15^{2 .{ }^{54}}$ This is perhaps an exaggeration, but unfortunately not a large one. And, equally unfortunately, the comment might also be applicable to certain types of letters one might write to a

stated: "It is not intended that section 152 should cover licensees unless in some other respects they do have an association with the Commission by reason of being a contractor or subcontractor or having money given to them by the Commission. But the mere fact of a person having a license does not mean necessarily that the product of his operation, if a patent should flow, would become publicly owned.

"While section 152 clearly prohibits the granting of patents on any invention or discovery in the atomic field 'made or conceived under any contract, subcontract, arrangement, or other relationship with the Commission;' it would be necessary to strain this language to blanket within the prohibitions those persons whose sole relationship with the Commission is a license granted by the Commission or the use under license of some special nuclear material owned by the Commision." I0o Cong. REc. I3783 (1954).

Senator Hickenlooper, then Vice Chairman of the Joint Committee, also stated: "It should be noted that this provision was not intended to apply to licensees of the Commission or to persons doing independent work, involving only a Commission security clearance, and not contractual arrangement." Id. at 14344 .

${ }^{22}$ See testimony of William Mitchell, AEC General Counsel, on February 4, 1955, in Hearings, supra note 47 , pt. I, at $x 99-200$.

es Benjalin N. Cardozo, The Growth of the Law 19 (1924).

${ }^{64}$ See Ooms, supra note 8 , at $284-85$. 
commission contractor. Indeed, section $15^{2}$ difficulties may sometimes be lurking in the most innocent kinds of telephone calls. ${ }^{55}$

There are two ways of trying to deal effectively with the host of problems created by section 152 . One is the obvious suggestion that this section of the law might be promptly amended. If any statutory provisions at all are needed to deal with inventions conceived during commission contracts-and it is extremely doubtful that they are, particularly in view of the general success with which the AEC has administered the patent clauses in its contracts and subcontracts ${ }^{56}$-then section $15^{2}$ could be amended so as to confine its scope to the essentials and, at the same time, clearly free from its threat those activities that ought not to be covered. But the prospect for an early legislative solution is not necessarily hopeful. The patent provisions of the act, it will be recalled, are among its most controversial features. Genuine difficulties might stand in the way of trying to open up section 152 without at the same time putting up for re-examination all the patent provisions of the act. And certainly, it would not be suprising to find in the Congress a disposition not to undertake any such general re-examination of the hard-fought patent provisions until more actual experience has been accumulated under the enactment of 1954.67

There is also available another remedy, and this one would not require legislative change. It does, however, call for boldness and clarity of action on the part of the Commission. The waiver power conferred upon the Commission by section $\mathrm{I}_{52}$ is, as we have seen, a very broad authority. The Commission "may waive its

${ }^{55}$ Section 152 also contains some rather complex and onerous procedural provisions which are intended to implement its substantive features. These procedural provisions are bound to create a number of problems for everyone, including particularly the Patent Office, but they are minor irritations as compared to the major substantive uncertainties that have been discussed.

${ }^{50}$ For a general description of the types of AEC patent clauses used in its contracts following the I946 act, see AEC Fifth Semiannual Rep. 150 (1949); and also the testimony of William Mitchell, AEC General Counsel, in Hearings, supra note 47, pt. I, at 193. The patent clauses undoubtedly will need some overhaul in the light of the purposes and provisions of the 1954 act; indeed, this by now may be somewhat overdue. But there is no ground for believing that the provisions of $\$ 152$ would provide any assistance or helpful guidance for that overhaul. It should also be noted that $\$ 159$ of the r954 act expressly declares: "Nothing in this Act shall affect the right of the Commission to require that patents granted on inventions, made or conceived during the course of federally-financed research or operations, be assigned to the United States." 68 STAT. 948, 42 U.S.C.A. \$2189 (Supp. 1954).

${ }^{57}$ At the time the compulsory licensing provisions were finally accepted by the House (see note 44 supra), Representative Cole stated that the Managers on the Part of the House were accepting the Senate's position on the understanding that the problem would be re-examined at the beginning of the next session of Congress. See 100 CoNG. REC. 1487I (1954). Representative Cole did introduce a bill at the next session which would have repealed the compulsory licensing provisions, and would also have amended $\$ I_{52}$ so as to greatly restrict its scope and eliminate many of the troublesome problems that are here being discussed. See H.R. 5167, 84th Cong., Ist Sess. (r955). Sce also Cole, Patenting Nuclear Developments, Nucleonics, April 1955, pp. 3x, 34, where Representative Cole states, with reference to $\$ 152$, of which he himself was the sponsor: "Ironically, under the pressure of zealously trying to protect the normal American patent system, too much was written into this section." During the first session of the Eighty-fourth Congress, the Joint Committee on Atomic Energy did not take action on either H.R. 5167 or any other patent proposals. See also Representative Cole's address of September 22, 1955, where, in addition to reiterating his vigorous opposition to the compulsory licensing provisions, he said with reference to \$152: "Unfortunately, there was insufficient opportunity for full discussion of this section and the past year has shown that this section needs to be revised." Aromic INDUSTRY REP. 5r:86 (1955). 
claim" under such circumstances as it "may deem appropriate." In connection with the Access Permit Program, the Commission has already determined that under section $1_{52}$ it may properly exercise this. waiver power in advance. ${ }^{58} \mathrm{Had}$ the Commission not done so in the case of the Access Permit Program, it is possible that the whole program would have faltered miserably. Similarly, the Commission appears to have it within its power-through regulation and general policy interpretations, as well as through rulings in particular cases presented-to determine in advance the general classes of cases in which the waiver power is to be exercised under section 152. This would probably involve a considerable administrative burden for the Commission. But that is a small price to pay for being relieved of the appalling uncertainties which section 152 will otherwise create. Somewhat in the alternative, the Commission could make a more general determination to waive the Government's rights under section 152 in all situations, except for specific cases where the Commission gives express notice in advance that this general waiver would not be deemed applicable. Thus, in one way or the other, it seems possible that the Commission itself, by heroic efforts, can overcome the unfortunate consequences of this poorly drafted section of the act.

${ }^{68}$ This is the Access Permit Program which is described in AEC Eighteenth Semuannual Rep. 102-03 (1955), and is discussed elsewhere in this symposium. See Green, Information Control and Atomic Power Development, stupra, 91-112. In the access permits which are being issued, the Commission includes the following advance waiver:

"In issuing the Access Permit, the Commission hereby waives, under Section 152 of the Atomic Energy Act of 1954 , ( $\mathrm{I}$ ) its rights in inventions or discoveries made or conceived in the course of, in connection with, or resulting from access to confidential restricted data provided under the terms of this Access Permit, and (2) its rights, except an irrevocable royalty-free, non-exclusive license for Governmental purposes, in inventions and discoveries made or conceived and which result from access to secret restricted data obtained in the course of, in connection with, or under the terms of this Access Permit." 